\title{
AN IMPLEMENTATION OF THAIR AND SHAIWA E-LEARNING KNOWLEDGE MANAGEMENT SYSTEM WITHOUT KNOWLEDGE ORGANIZER
}

\author{
Oloruntoyin Sefiu Taiwo ${ }^{*}$, Adeyemi Abdullahi Akanni ${ }^{1}$, Amao Taiwo Oluwadamilola ${ }^{1}$ \\ ${ }^{1}$ Department of Computer Science and Engineering, Ladoke Akintola University of Technology \\ Lautech University Rd 7, Ogbomosho, Nigeria. 212102 \\ *Email: oloruntoyin86@gmail.com
}

\begin{abstract}
The advent of e-learning has made unlimited source of knowledge available to us all. Recent research reveals great interest to introduce Knowledge Management (KM) ideas to e-Learning systems. It is argued that KM can facilitate an eLearning system. The joint studies of KM and eLearning point out the same fundamental goal: facilitating organizational learning. Researchers try to analyze the similarity of the goals, methods of assessment, and some knowledge sharing processes both in $\mathrm{KM}$ and eLearning. An eLearning system within $\mathrm{KM}$ is traditionally analyzed as a knowledge resource repository, where the KM methods can be implemented to increase the effectiveness of knowledge dissemination. Researchers have designed many models for integrating knowledge management into e-learning system. Some are practically implemented while some are not practically implemented. Despite these various models, researchers are still working for more interactive, efficiency and effective model that can be used to quickly identify the most relevant information (knowledge) and distribute it to meet specific needs. This work investigates the integration of e-Learning systems and Knowledge Management technology to improve, capture, organize and deliver large amounts of knowledge. First, a model is proposed for the phases of knowledge management. The model is then enhanced with concepts and technology from e-Learning. The model is then used to illustrate real world scenarios that add increasing amounts of knowledge management to an e-Learning environment. The system, AMID promises high interactivity, efficiency and effectiveness of integration of knowledge management and e-learning. In addition, the developed system will enhance technical learning process.
\end{abstract}

Keywords: e-Learning system, knowledge management, knowledge organizer

Abstrak: Munculnya e-learning telah membuat sumber pengetahuan yang tidak terbatas tersedia bagi kita semua. Penelitian terbaru mengungkapkan minat yang besar untuk memperkenalkan ide-ide Manajemen Pengetahuan (MP) ke sistem e-Learning. Dikatakan bahwa MP dapat memfasilitasi sistem e-Learning. Studi bersama MP dan e-Learning menunjukkan tujuan mendasar yang sama: memfasilitasi pembelajaran organisasi. Peneliti mencoba menganalisis kesamaan tujuan, metode penilaian, dan beberapa proses berbagi pengetahuan baik di MP maupun e-Learning. Sistem e-Learning dalam MP secara tradisional dianalisis sebagai gudang sumber daya pengetahuan, dimana metode MP dapat diimplementasikan untuk meningkatkan efektivitas penyebaran pengetahuan. Para peneliti telah merancang banyak model untuk mengintegrasikan manajemen pengetahuan ke dalam sistem e-Learning. Beberapa diimplementasikan secara praktis sementara beberapa tidak diterapkan secara praktis. Terlepas dari berbagai model ini, para peneliti masih berupaya untuk model yang lebih interaktif, efisien, dan efektif yang dapat digunakan untuk mengidentifikasi informasi (pengetahuan) yang paling relevan dengan cepat dan mendistribusikannya untuk memenuhi kebutuhan spesifik. Tulisan ini menyelidiki integrasi sistem $e$ Learning dan teknologi Manajemen Pengetahuan untuk meningkatkan, menangkap, mengatur dan memberikan sejumlah pengetahuan. Pertama, model untuk fase manajemen pengetahuan diusulkan. Model tersebut kemudian disempurnakan dengan konsep dan teknologi dari e-Learning. Model tersebut kemudian digunakan untuk mengilustrasikan skenario dunia nyata yang menambah jumlah manajemen pengetahuan yang meningkat ke lingkungan e-Learning. Sistem, AMID menjanjikan interaktivitas tinggi, efisiensi dan efektivitas integrasi manajemen pengetahuan dan e-Learning. Selain itu, sistem yang dikembangkan akan meningkatkan proses pembelajaran teknis.

Kata Kunci: knowledge organizer, manajemen pengetahuan, sistem e-Learning

\section{Introduction}

Fall (2002), described Artificial Intelligence (AI) as the computational models of human behavior (Programs that behave externally like human), computational models of human thought (Program that operate internally the way humans do), computational systems that behave intelligently, computational systems that behave rationally (Program that takes actions it believes will enable it to achieve its goals) 
and AI applications (Program that offer e-leaning, program that monitor trades, program that detect tract fraud and program that shuttle loading).

John (2005), explained that Artificial Intelligence consists of many sub-fields, using a variety of techniques, such as:

i. Expert Systems, Example: decision support systems, e-learning systems.

ii. Neural Networks, Example: brain modeling, time series prediction, classification.

iii. Evolutionary Computation, Example: genetic algorithms, genetic programming.

iv. Vision: Example, object recognition, image understanding.

v. Robotics: Example, intelligent control, autonomous exploration.

vi. Speech Processing, Example: speech recognition and production.

vii. Natural Language Processing, Example: machine translation.

viii. Planning: Example, scheduling, game playing.

ix. Machine Learning, Example: decision tree learning, version space learning.

Expert systems are one of the prominent research domains of artificial intelligence. Expert system is a popular method for representing large bodies of knowledge for a given field of expertise and solving problems by use of this knowledge. (Griffin \& Lewis, 2011) described an expert system often consists of three parts, namely: a knowledge base, an inference engine, and a user interface. He (Griffin \& Lewis, 2011), further explained that a dialogue is conducted by the user interface between the user and the system. The user provides information about the problem to be solved and the problem to be solved and the system they attempts to provide insights derived (or inferred) from the knowledge base. These insights are provided by the inference engine after examining the knowledge base. The Interaction is illustrated by the picture in figure1.1 below

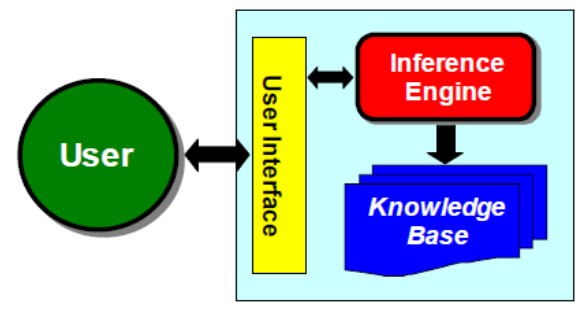

Figure 1. An expert system (Griffin \& Lewis, 2011)

Utilization of experts system is particularly spread in the area of e-learning; experts system is applied in Knowledge Management; knowledge creation, knowledge dissemination and usage of knowledge (Olirera \& Zita, 2011). Expert system provided the possibility of collection, storing, organizing, interpreting and distributing knowledge to users at their access point in order to meet the goals of elearning (Olirera \& Zita, 2011). The Gartner Group, a leading research and consulting firm predict that "By 2003, 70 percent of enterprises implementing Knowledge Management (KM) will link it with elearning technically and organizationally" (Aldrich, 2000). The ability to learn and to manage learning becomes critical to the success of organizations. So, effective management of knowledge is getting widely concerned and Knowledge management technology is now used to rapidly capture, organize and deliver large amounts of corporate knowledge. Many firms adopt knowledge management initiatives to facilitate the sharing and integration of knowledge, like integrating knowledge management with ELearning. We're beyond the industrial age, slipping off the edge of the information age into knowledge age and seeing the convergence of knowledge management and learning (Thair \& Shaima, 2014).

According to Cross (2006), more than eighty percent of workplace learning is now done outside the formal learning environment of sponsored classes and training; In other words, most learning is now done outside the traditional face-to-face environment. The challenges to leaning in knowledge are now effectively helping learners to acquire knowledge and skill, helping learners how to manage, work creatively with ideas and to contribute to the new knowledge. 
$\mathrm{KM}$ is the management of processes that govern the creation, dissemination, and utilization of knowledge by merging technologies, organizational structures and people to create the most effective learning, problem solving and decision making in an organization (Sammour et al., 2008).However, elearning can be defined as the formally and systematically organized teaching and learning activities in which the instructor and the learner(s) use ICT to facilitate their interaction and collaboration(Sammour et al., 2008). Therefore, e-learning can take several forms like, Web-Based Training (WBT), electronic support systems, Computer-Based Training (CBT), listservs, webcasts, interactive broadcasts, discussion forums, and so on.

Recent research shows great interest in integrating Knowledge Management (KM) ideas to e-learning systems. The collaboration of e-learning and KM point out the same fundamental goal: facilitating organizational learning. Researchers try to analyze the joint studies goals, model (method of assessment and knowledge sharing processes), impact and challenges. The challenges to learning in knowledge societies are not limited to how effectively helping learners to acquire knowledge and skills, but in helping them to learn how to manage, work creatively with ideas and to contribute to the creation of new knowledge"(Wang \& Yang, 2009). This study provide a literature pertaining to Integration of Knowledge Management in to e-leaning system, the research to capture and reveal related patterns that are shared in past research to provide better understanding and insight into the future direction. The aim of this research is to develop a knowledge management model, develop an e-learning system that uses the model developed knowledge management model as backend and to evaluate the developed system.

The advent of e-learning has made unlimited source of knowledge available to us all. Recent research reveals great interest to introduce Knowledge Management (KM) ideas to e-Learning systems. It is argued that KM can facilitate an eLearning system. The joint studies of KM and eLearning point out the same fundamental goal: facilitating organizational learning. Researchers try to analyze the similarity of the goals, methods of assessment, and some knowledge sharing processes both in KM and eLearning. An eLearning system within KM is traditionally analyzed as a knowledge resource repository, where the KM methods can be implemented to increase the effectiveness of knowledge dissemination. Researchers have designed many models for integrating knowledge management into e-learning system. Some are practically implemented while some are not practically implemented. Despite these various models, researchers are still working for more interactive, efficiency and effective model that can be used to quickly identify the most relevant information (knowledge) and distribute it to meet specific needs. Also, looking around, student's especially tertiary education suffers a lot of setback. Some of the problems affecting student in the tertiary institution are stated below.

i. Inadequate lecture halls

ii. Inadequate learning facilities/problem of teaching

iii.Problem of Insecurity

iv. Problem of hostel accommodation

v. Problem of access road to the school which posses a lit of problem directly to the student

vi. Problem of cult activities which render the killing of students.

As a result of the above mentioned problem, many students feel reluctant to study; this calls for the attention of researchers to integrate knowledge management in to e-learning system. The integrated models proposed by Thair \& Shaima (2014) and Woelk \& Agarwal (2003); It can be deduced that the existing system involved too much chains of activities which affect the speed, effectiveness and efficiency of the system. There is a need to provide better way of incorporating knowledge management into elearning system.

\section{Materials and Methods}

In order to achieve the aim and objective stated above, the proposed model will be developed for a web-based system, whose accessibility is very easy in Nigeria. The methodology that will be employed in the development of this system are:

i. Design of the easy-to-use user interface for the system. 
ii. Design a portion for knowledge holder to signup/register in other to have access to create knowledge for knowledge seeker.

iii. Design a portion for knowledge seeker to signup/register in other to have access to knowledge created by knowledge holder.

iv. Inference engine to serve as a search engine and work as intermediary between knowledge repository and knowledge holder/seeker using backward chaining method to execute its actions.

v. Development of knowledge repository that can be searched and quickly retrieved the data stored in it.

vi. Design of knowledge holder box to serve as user's feedback and enables comment, evaluation from the knowledge seeker and knowledge holder.

This research will attempt to provide benefit to individuals who are ignorant of the importance of knowledge management into an e-learning. More so, it offer support to the process of integrating knowledge management into e-learning system by developing an e-learning system that use knowledge model as it backend and to evaluate the system developed.

In addition, it also aims to be of benefit to researcher in the nearest future. Hence it serves as a reference point for further researcher and a blue print for integration of knowledge management in an e-learning system.

In this section, we present the history of the work and some of previous researches that have been done on Integration of knowledge management into e-learning and other related topics. More so, we review some of the approaches and models that had been used for integration of knowledge into elearning system.

\section{Result and Discussion}

\section{A. Existing System}

1. Integration of E-Learning and Knowledge Management

Woelk \& Agarwal (2003) suggests a fifth phase of knowledge management. However Nonaka \& Takeuchi (1995) have described four phase of knowledge management: socialization, externalization, combination and internalization and their implementation in the tacit knowledge to explicit knowledge. This suggestion that there is a fifth phase: cognition which is the application of knowledge that has exchanged through the other phase. Figure 2 show the knowledge management phase.

i. Socialization: Transfer tacit knowledge from one person to another person.Externalization:

ii. Translate tacit knowledge into explicit knowledge in a repository.

iii. Combination: Combine different bodies of explicit knowledge to create new explicit knowledge.

iv. Internalization: Extract the explicit knowledge from a repository that is relevant to a particular person's need and deliver it to that person where it is translated into tacit knowledge.

v. Cognition: Apply tacit knowledge to a business problem.

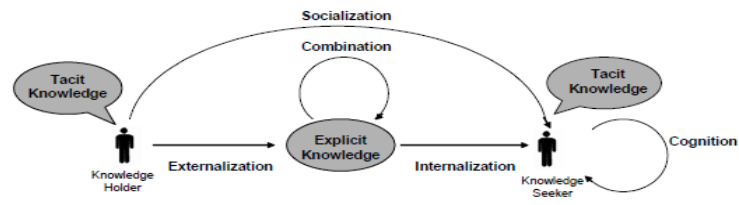

Figure 2: Knowledge management phase (Nonaka \&Takeuchi, 1995)

More so, Woelk \& Agarwal (2003) investigate that e-learning technology has been evolving separately from knowledge management technology. E-learning technology will enhance the effectiveness of each of the five phase of knowledge management as show below. A sixth phase, feedback has been added.

i. Socialization: Competency and skills measurements help identify the people with specific interests, skills and knowledge in the organization. 
ii. Externalization: Knowledge is captured by the system with the intent of teaching that knowledge to other people. This improves the knowledge capture process.

iii. Combination: Knowledge about products and processes of the business is organized to make learning the knowledge more effective and efficient. Pedagogical techniques are embedded in the knowledge.

iv. Internalization: Competency and skills measurements help identify which people lack the knowledge to do their job effectively and provide them with online training. E-Learning will insure that a person has learned the knowledge using assessments and alternative learning methods, if necessary.

v. Cognition: People can be provided with on demand performance support by getting just the training that they need at the time that they need it to complete a business task.

vi. Feedback: Assessments provide feedback concerning how well a person has learned and how well they have applied what they learned to a business problem.

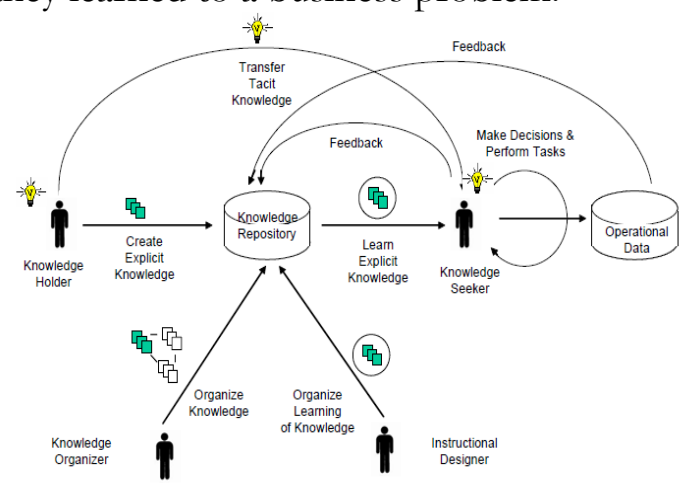

Figure 3: Knowledge management phases with e-Learning enhancements (Woelk \& Agarwal, 2003)

Figure 3 is a modified and more detailed version of Figure 3 that represents the knowledge management phases with e-Learning enhances documents. In Figure 3, a Knowledge Holder can either transfer tacit knowledge to a Knowledge Seeker through socialization or create explicit knowledge and store it in a knowledge repository. The Knowledge Organizer in Figure 3 is a person (or software program) who relates the created knowledge to other knowledge in the repository or further refines the created knowledge. The Instructional Designer is a person (or software program) who organizes the learning of the knowledge by adding pre-assessments, additional learning aids, and post-assessments. The Knowledge Seeker then learns the explicit knowledge through an online guided learning experience. The Knowledge Seeker then uses the knowledge gained through socialization or internalization to make decisions and perform tasks in the enterprise. The performance of the Knowledge Seeker on these decisions and tasks is measured and returned to the knowledge repository as feedback that can be used to help determine if the skills have been learned and to suggest additional e-Learning experiences.

This method (Woelk \& Agarwal, 2003) was applied to Business scenario: business scenario traditional e-learning, business scenario e-learning based on enterprise content, business scenario elearning based on enterprise knowledge and business scenario digital publishing. The first three scenarios concentrate on increasing the effectiveness of the performance of employees in meeting the objectives of the company. This requires that an employee receive the "right knowledge" at the "right time" and "just enough" knowledge that they need to execute effectively.

The strength of (Woelk and Agarwal, 2003) system is that there is a successful implementation of integrating of e-learning and knowledge management. The model was applied to some real world scenarios to illustrate the benefits of the integration. These scenarios also provide a roadmap for the evolution of the new system that will provide both the efficient of knowledge and the efficient delivery of knowledge. The limitation of the system is that the system is costly because of the knowledge organizer maintainability.

2. The Role of Knowledge Management and E-Learning in Professional Development 
Sammour et al. (2008) described knowledge management as a techniques that can be used to capture, organizes and deliver knowledge and management system. He discussed the basic concepts of knowledge management and e-learning and how can be integrated and leveraged for effective online education and training. Similarly, he illustrates the role of knowledge management and e-learning in professional development. The role is related to the following:

i. Knowledge creation and acquisition - Knowledge creation and acquisition depend on nurturing people with knowledge - either individually or in teams or in communities of practice - and how knowledge is or can be acquired. The focus is on passive run conscious knowledge acquisition.

ii. Knowledge sharing - This takes place when people are genuinely interested in helping one another develop new capacities for action; it is about creating learning processes.

iii. Knowledge capture - Knowledge has to be selected, chosen and archived. Here the challenge is capturing tacit knowledge as well as explicit knowledge. It is important to establish processes in order to formalize knowledge preservation. This knowledge has to be captured and stored in databases.

iv. Knowledge application - The knowledge created and captured would then need to be applied to achieve competitive advantage.

v. Knowledge evaluation - It must be reviewed to verify that it is relevant and accurate.

The above-described processes work in a cyclical manner as depicted in Figure 4, taking into consideration that for knowledge creation and acquisition to take place, knowledge needs should be clearly determined in the context of the organizational scope. An inventory of existing knowledge also may exist, which helps in creating and acquiring new knowledge.

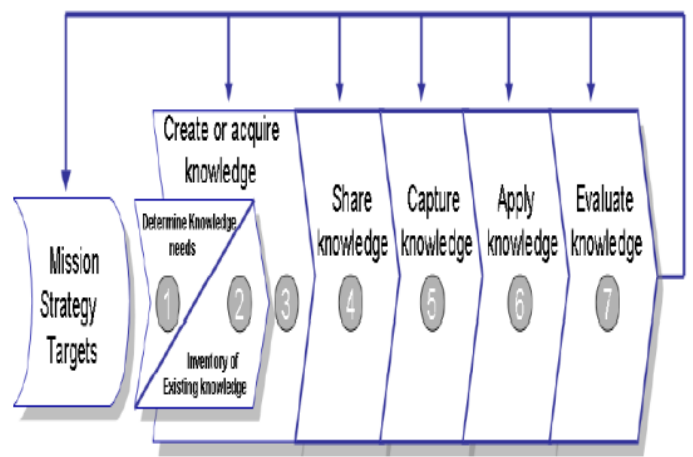

Figure 4. Knowledge management processes (Sammour et al., 2008)

More so, Sammour et al. (2008) integrated the learning cycle within the knowledge management cycle; Figure 4 shows the integrated mode and some of the possible event that take place at each process in the cycle within the organization.

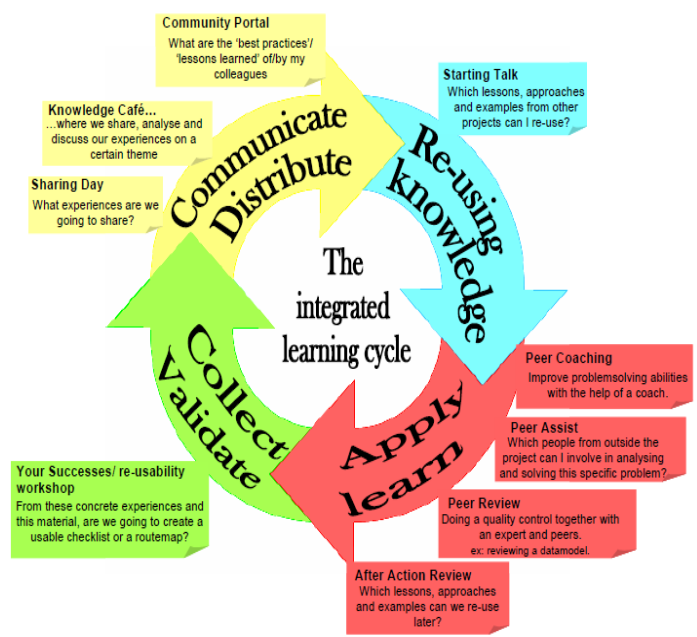

Figure 5. The integrated knowledge management learning cycle (Sammour et al., 2008) 
The strength of the model (Sammour et al., 2008) successfully implements the process of KM in context learning: knowledge creation and acquisition, knowledge sharing, knowledge capture, knowledge application knowledge evaluation. The disadvantage of the model is that the knowledge management was not successfully integrated into e-learning system.

\section{B. A Framework for E-Learning as A Tool for Knowledge Management}

Rosemary et al. (2002) proposed a framework for the e-learning process, which includes the factors to consider before doing online, the key element of the effective online education, and the important elearning implementation considerations. The framework was tie to the processes in the knowledge value chain to illustrate how e-learning is used as an important tool in knowledge management. However, elearning is not meant to replace the classroom setting, but to enhance it, taking advantages of the new content and delivery technologies to enable learning. Figure 6 depicts an e-learning value chain that represents the e-learning planning process, which can be directly linked to the knowledge management value chain.



Figure 6. E-Learning value chain (Rosemary et al., 2002)

More so, the element of the e-learning planning process include assessing and preparing organizational readiness (factors to consider before going online), determining the appropriate content (content that ties into the goals of knowledge management), determining the appropriate presentation model (considering factors contributing to effective e-learning), and implementing e-learning (content technology infrastructure consideration) organizational readiness is directly tied to the first process in $\mathrm{KM}$ value chain, i.e. it requires the determination of strategic knowledge requirement and an assessment of the current organizational knowledge gap. The last two processes in the knowledge value chain (closing the knowledge gap and disseminating the knowledge acquired) are aligned with the last three phases of the e-learning value chain.

The proposed framework is showed in Figure 7, the strength of the framework of knowledge content and the presentation and the subsequent e-learning implementation close the knowledge gap and disseminate the knowledge required to promote organizational survival and improve its competitive position. Furthermore, the combination of some elements of effective traditional learning with characteristics of online learning produce a successful e-learning environment.

Finally, the drawback of the framework is that there is no involvement of the development of a technical infrastructure, paradigm shifts in organizational behavior and design of knowledge strategy, and economic investments. 


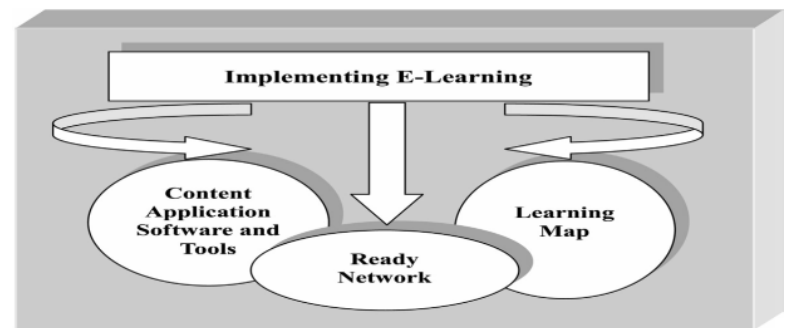

Figure 7. Implementation of E-Learning (Rosemary et al., 2002)

1. The Design of An E-Learning System Beyond The Hype

Ismail (2002) developed learning design system and described a framework for e-learning design system as a crucial in guiding the decision relating to the choice and development of each component in relation to the objective outlined in the organizational e-learning strategy. The framework specifies learning system architecture for pedagogical development and systems integration. In addition, he described one such framework that is showed in Figure 8. The framework is a conceptual model, representing the information flow and linkage between various modules and the interaction between main processes with the learning value chain.

This framework provides a means for organizations to systematically envision and craft their elearning system while maintaining interoperability with party application and content. The learning design system developed by (Johan, 2002), allow content producers to quickly analyze and design instructional sound learning program. The LDS also provide a project management capability that incorporates an instructional design methodology. In addition, LSD produces a storyboard and flowchart of the complete structure of the final product. This structure consist of learning object can be used by content developers to develop instructional materials. Figure 9 showed below the learning design system (LDM) for elearning application.

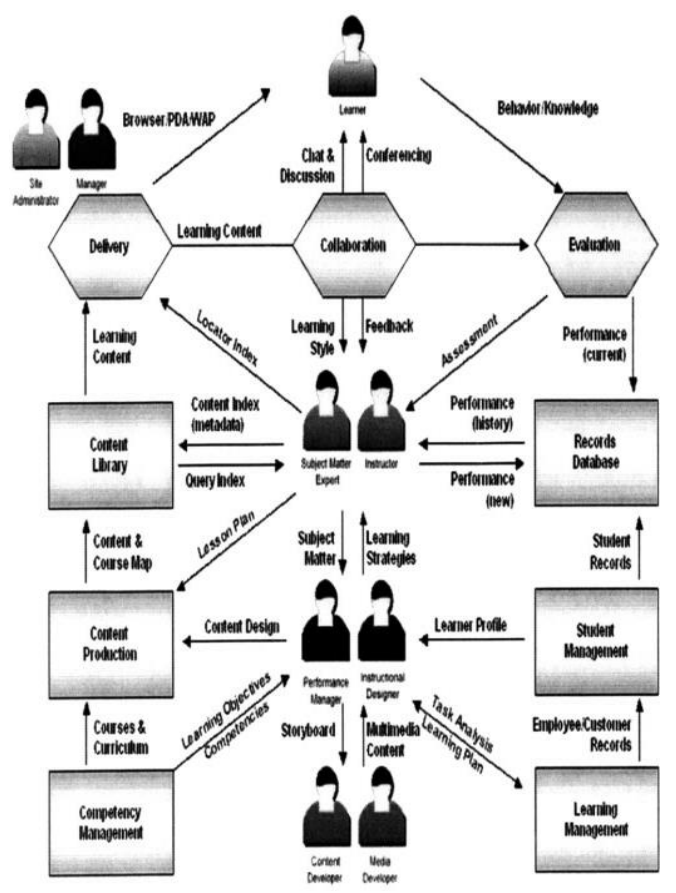

Figure 8. E-learning systems framework (Ismail, 2002)

The LCMS provided a collaborative authoring environment for creating and maintaining learning content. Within the LCMS, work flow processes are activated to coordinate collaborative authoring of learning content. The potential benefit of the system is that the LCMS bridges provide the developer 
with tools and functionality required to produce and manage effective learning content. The LCMS allows organization to:

i. Capture the knowledge within the organization

ii. Structure the knowledge into focused, directed learning programs.

iii. Incorporate third party content

iv. Achieve rapid updates, dissemination, management, and utilization of that knowledge throughout the organization.

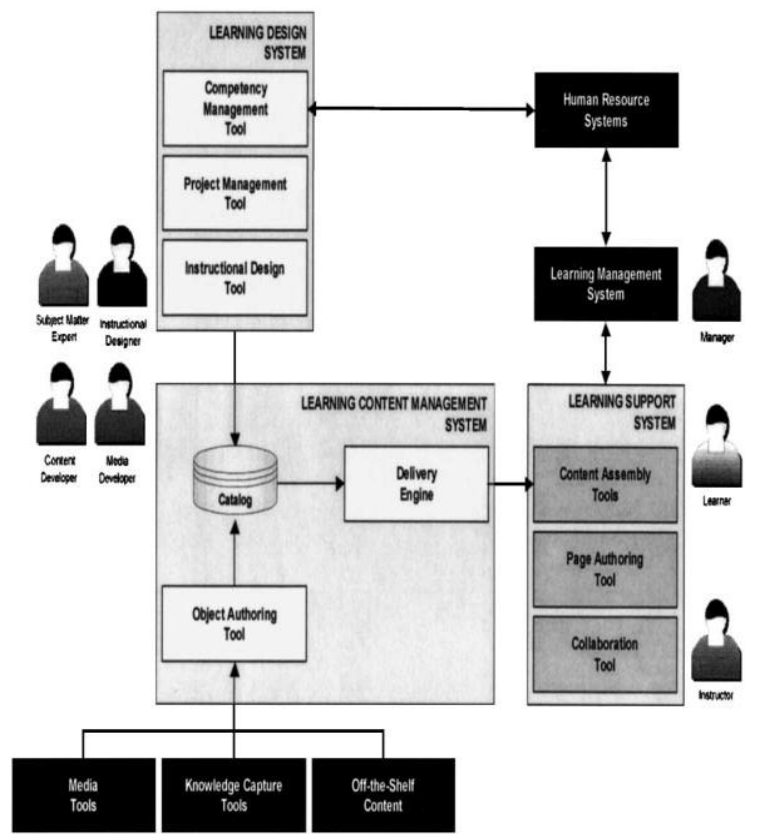

Figure 9. E-learning applications (Johan, 2002).

The drawback of the system is that products in learning management systems do not address the need to develop and manage increasing volumes of content in smaller chunks by a larger group of content providers, nor do they provide adequate mechanisms for maintaining consistent instructional presentation or adapting that content to the needs of learners.

\section{System Analysis and Design}

This session provides a detailed design of the proposed integrated system called AMID, by showing the required architecture of the system with steps in achieving this system. This is an attempt to develop a knowledge management model; develop an e-learning system that use KM model as backend and to evaluate the system developed. This proposed AMID system will enhances the rapid capture, organize knowledge and deliver large amounts of corporate knowledge. In addition it also facilitates organizational success and growth.

1. Analysis of The Existing System

The existing system of knowledge management system in line with E-learning is often found to incorporate a Knowledge Organizer who fetch knowledge that is created by a knowledge holder from the knowledge repository and separate or organize the knowledge base on their category before saving the knowledge to their appropriate places, the second party in the existing system is known as Instructional Designer who organize the learning of the knowledgebase on a predefined instructions before knowledge seekers can access the knowledge in the repository. Figure 3 in chapter showed the graphical representation of the existing system.

It can be deduced from the above that the existing system involved too much chains of activities which may affect the speed, effectiveness and the efficiency of the system. Hence this research work has been necessitated to provide better way of incorporating Knowledge Management into E-learning System; this will be detail in the analysis of the proposed system. 
2. Analysis of The Proposed System

The proposed system aimed to make Knowledge Management and E-learning System more speedy, effective, interactive and efficient by replacing the duties of Knowledge Organizer and Instructional designer with "Inference Engine". The Inference Engine in this regard will be responsible to organize the knowledge that is being deposited by the knowledge holder into the repository as well as to organize the learning modality base on some predefined conditions before knowledge seekers can access it from the repository and make use of it.

It worth mentioning that the introduction of Inference Engine into the system will make the result of the system to be more accurate, it will avoid data redundancy, it ensure data integrity, it will avoid duplicate of data and it will give a timely result. The knowledge in question in this research work would come in form of Text Format. Figure 10 show the use case Diagram of The Knowledge Holder and The Knowledge Seeker. More so, Figure 11 showed the activity diagram of the proposed system. It can be deduced from Figure 10 that both users (Knowledge Holder and Knowledge Seeker) of the system must be register on the system before they can make use of it. After registration the Inference Engine determines the category the registered user belong and position them into the appropriate places. It also worth mentioning that users are restricted to their domain alone i.e. they can only perform activities that domicile in their module alone.
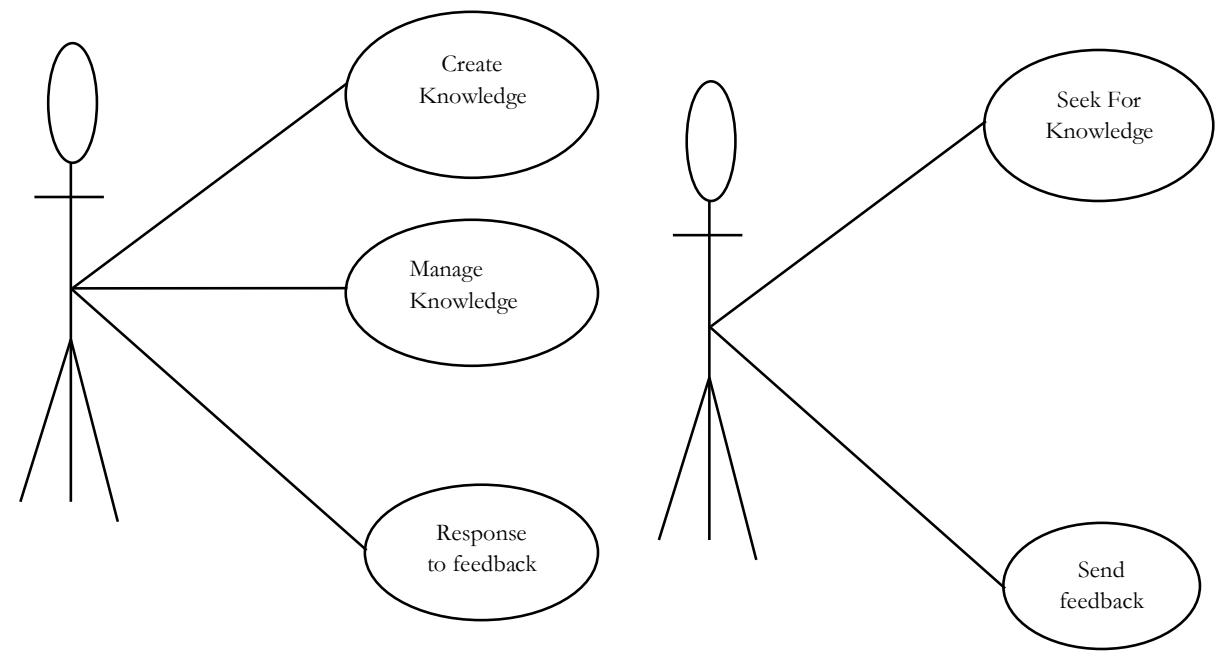

Figure 10. Use case diagram of the knowledge holder and the knowledge seeker

\section{System Design}

The objective of incorporating Inference Engine into the existing system to replace the Knowledge Organizer and Instructional Organizer is to make the system more speedy, effective and efficient. The design phase takes decisions as starting and assembles all the particulars of the new system. The end product of the design phase was a set of operating procedures including computer programs and hardware specifications needed to implement the propped system. 


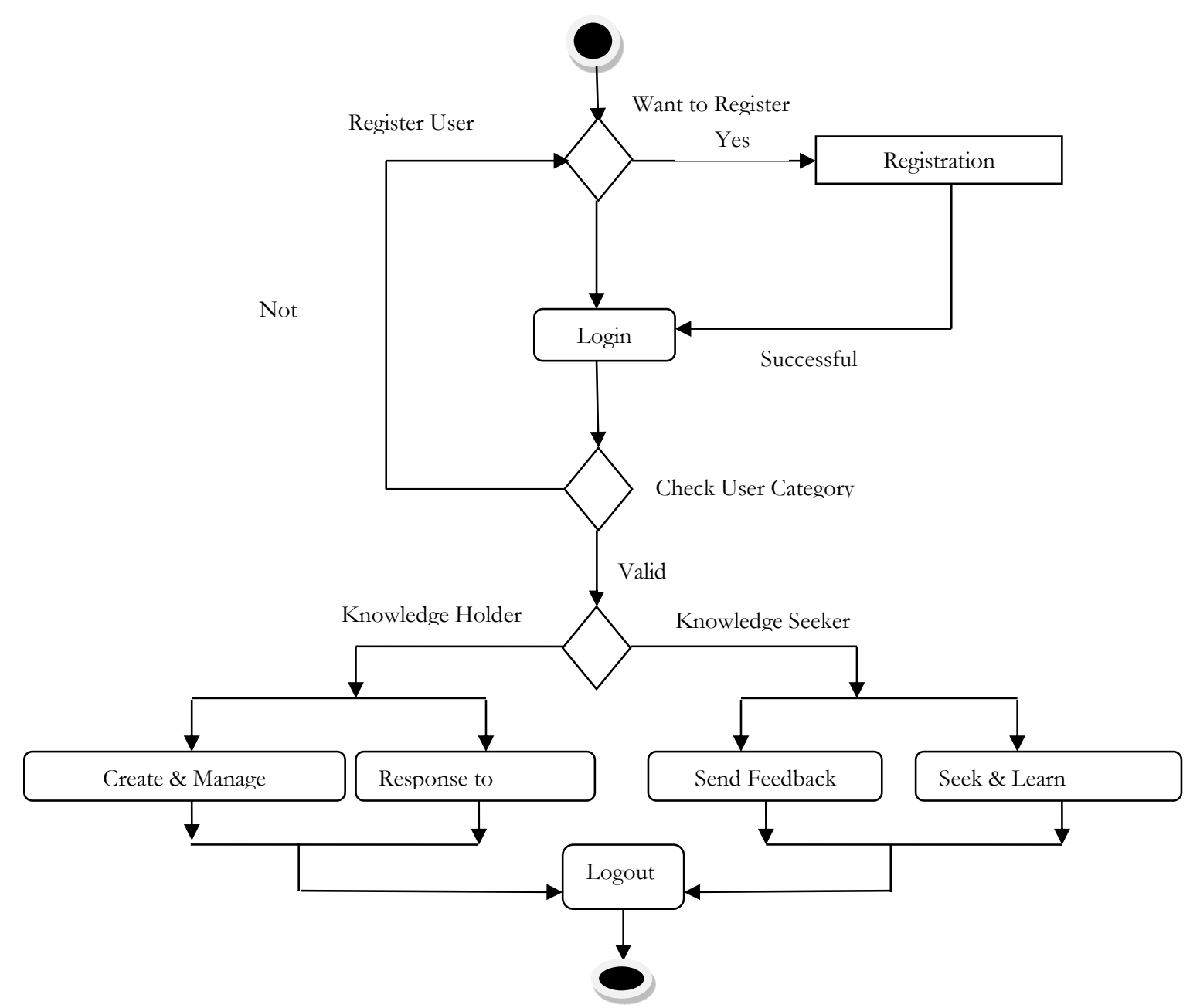

Figure 11. Activity diagram of the proposed system

\section{Database Design}

A database is simply a repository of data information on the computer. It is analogue to an electronic filing system. However, there are some basic attributes associated with database that make it suitable for efficient storage and retrieval of information. Table 1 shows the tables that will be in the proposed system.

Table 1. Login table

\begin{tabular}{ccc}
\hline Field Name & Data Type & Field Size \\
\hline User ID & number & 5 \\
Username & Varchar & 30 \\
Password & Varchar & 15 \\
Role & Varchar & 15 \\
\hline
\end{tabular}

Table 1 shows the login table which the Inference Engine would use to authenticate the users login as well as their role in the system.

Table 2. Knowledge holder

\begin{tabular}{lcc}
\hline Field Name & Data Type & Field Size \\
\hline ID & Number & 5 \\
Name & Tex & 20 \\
Knowledge_to_be_deliver & Varchar & 20 \\
\hline
\end{tabular}


Table 3. Knowledge seeker

\begin{tabular}{lcc}
\hline Field Name & Data Type & Field Size \\
\hline ID & Number & 5 \\
Name & Varchar & 20 \\
Level & Varchar & 10 \\
\hline
\end{tabular}

Table 4. Knowledge

\begin{tabular}{lcc}
\hline Field Name & Data Type & Field Size \\
\hline ID & Number & 5 \\
Knowledge_Name & Varchar & 20 \\
\hline
\end{tabular}

\section{Knowledge Repository}

The knowledge repository in this research work would be a special kind of database for knowledge management. It would provide the means for the computerized collection, organization, and retrieval of knowledge. The terms database and knowledge repository are mostly used synonym. The major difference is that a database is a concrete technical solution to store and Organize data - it is mostly also limited on just these functionalities. In contrast to that, a knowledge repository is a technology to store "knowledge". For this purpose it can use a database, but it is not limited on these functions. A knowledge repository can use many databases or can combine or enrich it with information from public data sources. Hence, a knowledge repository is more or less big and a heterogeneous source for many kinds of information.

The knowledge repository in this context would be where the knowledge holder created or deposit knowledge for the knowledge seeker to seek and make use of it. Below is the rule or algorithm for the knowledge repository and knowledge holder:

a. Check knowledge holder access details

b. If valid, proceed and create knowledge else GOTO 1

c. Validate the created knowledge

d. If valid proceed, else GOTO 2

e. Check the category of the knowledge

f. If knowledge is for class A, deposit the knowledge in category A

g. If knowledge is for class $\mathrm{B}$, deposit the knowledge in category B

h. If knowledge is for class $\mathrm{C}$, deposit the knowledge in category $\mathrm{C}$

i. If knowledge is for class $\mathrm{D}$, deposit the knowledge in category $\mathrm{D}$

j. Validate, if valid deposit else GOTO 5

k. End

Below is the rule or algorithm for the knowledge repository and knowledge seeker

a. check if knowledge seeker access details

b. if access valid proceed, else GOTO 1

c. seek for knowledge

d. if knowledge is available proceed, else GOTO 3

e. acquire knowledge

f. end

\section{Knowledge Seeker}

Knowledge Seeker learns the explicit and tacit knowledge through an online guided learning experience (AMID). The knowledge seeker then use the knowledge gained through the system. The performance of the knowledge seeker is measured and returned to the knowledge holder as feedback; that can be used to determine if the skills have been learned and to suggest additional e-learning experiences.

6. Knowledge Holder

These are the person who insert or input knowledge into the system. These people acquire knowledge and place it according to it categories in the system. However, they have access to input data or update data into the knowledge repository but they don't have access to delete data in the knowledge 
repository. More so, they also receive feedbacks (complaints, question, comments and advice) and also give response to the knowledge seekers.

\section{System Implementation}

1. System Development

This chapter captures all the activities that take place in the conversion of the old system to a new system. System implementation is the chapter is the way and execution of detailed design of a AMID System in to actual operation. AMID System was developed using PHP programming language and MySQL programming language. The implementation of the system can be summarized as below; developing Knowledge management model and develop e-learning system that uses the model as backend and to evaluate the system. The evaluation stage is actually to see if the new system developed met the required aims and the objectives of the project.

\section{Operation of the System}

AMID is a web application that allows collection, storing, organizing and distributing of knowledge at more speedy, effectively, interactive and efficiently between knowledge holder (lecture) and knowledge seeker (student). The following are the user guidelines on how to use AMID system:

i. Ensure that XAMPP is already installed on the system. Xampp control server as server for AMID System

ii. Open your browser and $\log$ in to local address 127.0.0.1/edu/

iii. A page (AMID graphical User Interface)

iv. Register as a knowledge Holder (Lecturer) or Knowledge seeker (student)

v. After successful registration proceed to login page. Login as knowledge seeker/ knowledge holder.

vi. After successful login as knowledge holder (Lecturer). Knowledge holder will have access to publish course material, post information, give Assignment and also viewing knowledge seeker

vii.Successful login as knowledge seeker (student) will have access to download material, submit assignment and chat with other knowledge seeker

3. Design of AMID System

AMID is a knowledge management application which provides the tools and properties required to collecting, storing, organizing and distribution of knowledge at more speedy, effectively, interactive and efficiently.

\section{Conclusion}

The advent of e-learning has made unlimited source of knowledge available to us all. Researchers have designed many models for integrating knowledge management in to e-learning system. Some are practically implemented while some are not practically implemented. Despite of this various models, researchers are still working for more interactive, efficiency and effective model. For this reason, AMID is designed as web application that improves the interactive, efficiency and effectiveness of knowledge management system. Many people such as student, lecturer, and researchers mostly use internet to acquire and disseminate knowledge. AMID system facilitate knowledge creation and acquisition, knowledge capturing, knowledge evaluation and knowledge sharing at any convenient time and location. The system is implemented using PHP and MySQL and the system is tested. The use of Knowledge Management in e-learning will definitely impact the quality of the education that is delivered and the deliverability of information through knowledge and information sharing.

\section{References}

Aldrich, C. 2000. The Learning Revolution. Gartner Symposium, IT XPO 2 Orlando, Florida.

Alrawi, K. 2010. How knowledge management adds critical value to e-learning media. Journal of Knowledge Management Practice 11(3): 78-83.

Bullinaria, J.A. 2005. IAI: The Roots, Goal and Sub-fields of AI. https://www.cs.bham.ac.uk/.

Cross, J. 2006. Informal Learning: Rediscovering The Natural Pathways That Inspire Innovationand Performance. San Francisco: John Wiley \& Sons. 
Darrel, W., \& A. Shallesh. 2003. Integration of e-Learning and knowledge management. World Conference on E-learning in Corporate Government, Healthcare, and Higher Education: 1035-1042.

Elrehail, H.H., M.A. Trad., \& K.M. Algraibeh. 2013. Applying knowledge management oriented objective into distance elearning process and strategist. Management 3(2): 316-322.

Fall. 2002. 6.825: Techniques in Artificial Intelligence A graduate level course of MIT open course mare, develop by Leslie Kaelbling. lecture 1: pp.1-6.

Gogos, R. 2013. A brief history of e-learning (inforgraphic). www.efrontlearing.net/blog/2013/08/a-briefhistory-of elearning infographic.html.

Grljeric, O., \& Z. Bosnjak. 2011. Knowledge management in expert systems development. Management Knowledge and Learning International Conference: 487-495.

Ismail, J. 2002. The design of an e-learning system beyond the hype. Internet and Higher Education 4: 329-336.

Judrups, J. 2015. Analysis of knowledge management and e-learning integration models. Procedia Computer Science 43: 154-162.

Khdour, T., \& S. Salem. 2014. The effects of integrating knowledge management with E-learning system. Proceeding of 2014 Zone 1 Conference of the American Society for Engineering (ASEE Zone 1): 1-6.

Minhong, W., and S.J.H. Yang. 2009. Editorial: Knowledge management and E-learning. Knowledge Management \& E-Learning: An International Journal 1(1): 1-5.

Moore, J.L., C. Dickson-Deane., \& K. Galyen, 2011. e-Learning, online learning, and distance learning environment: Are they the same?. The Internet and Higher Education 14(2): 129-135.

Nonaka, I., \& Takeuchi, H. 1995. The Knowledge-Creating Company: How Japanese Companies Create The Dynamics of Innovation, $1^{\text {st }}$ Edition. New York: Oxford University Press.

Owayid, A.M., K. Alrawi., \& K. Shaalan. 2013. The effect of information systems infrastructure and staff involvement in the integration of knowledge management and e- learning technologies in academic institutions. Cambridge Business \& Economics Conference: 1-26.

Prusak L. 2001. Where did Knowledge Management Come From? IBM Systems Journal 40(4): 1002-1007.

Sammour, G., Schreurs, J., Al-Zoubi, A.Y., \& Vanhoof, K. 2008. The role of knowledge management and e-learning in professional development. International Journal, Knowledge and Learning 4(5): 465-477.

Wild, R.H., K.A. Griggs., \& T. Downing. 2002. A Framework for e-learning as a tool for knowledge management. Industrial Management \& Data Systems 2(2): 371-380. 